\title{
Older Workers' Emotional Reactions to Rising Retirement Age: The Case of the Netherlands
}

\author{
Hanna van Solinge ${ }^{1,2}$ and Kène Henkens ${ }^{1,2,3}$
}

\author{
1. Department of Work and Retirement, Netherlands Interdisciplinary Demographic Institute (NIDI), The Hague, the Netherlands \\ 2. Department of Health Sciences, University Medical Centre Groningen, Groningen, the Netherlands \\ 3. Department of Sociology, University of Amsterdam, Amsterdam, the Netherlands
}

\begin{abstract}
All over the world the retirement landscape is changing. Probably one of the bigger and more fundamental changes is the rise in the pension eligibility age. The fact that these reforms came quickly after the closing of early retirement opportunities urged the pre-pension cohorts to adjust their retirement outlooks. This research studied older workers' emotional reactions to reforms that induce them to extend their working lives with a number of years. Using data from a large scale sample survey among 6,800 older workers in the Netherlands, aged 60-65 at time of interview in 2015, we examined why the pension reforms trigger stronger emotional reactions in some individuals than in others. We integrated theoretical insights from the theory of emotion and the resource-based perspective on retirement adjustment. Testing our hypotheses revealed that emotions are stronger among individuals that have less access to resources. Anger and worry is more prevalent among older workers in more demanding jobs, with less favorable personal (health, wealth) and social resources (no partner support). This research suggests that policy makers-mostly higher level professionals who are much less exposed to the challenges of working longer-have underestimated the psychological and social impact of the reforms on vulnerable groups of older workers and, in particular, less educated older workers with lower social status. With a further increase of retirement age to be expected, policy makers are challenged to design policies that spare vulnerable groups in particular, for example, by facilitating more flexibility in the retirement transition.
\end{abstract}

Everywhere in the Western world, retirement conditions are changing. Concerns regarding the long-term sustainability of the welfare state have urged national governments to redesign their pension systems. Most OECD countries are using more or less similar strategies. Starting with reforms that reduce early retirement incentives, followed by raising pension eligibility ages (OECD, 2015).

The Netherlands was no exception in this respect. After some minor modifications of the system in the 1990s, which did not had the desired effect on the effective retirement age, new reforms were taken into effect in 2006, blocking early retirement arrangements in the second pillar pensions for cohorts born in 1950 and later. In 2012, government decided to gradually rise the state pension eligibility age till age 67 . In 2015, the pace of rising the pension age has been increased. Many other European countries, like the UK, Italy, France and Germany, have recently increased their retirement ages as well (OECD, 2015). There have been many protests across Europe around pension issues, such as large demonstrations and strikes in France and Italy, and the foundation of the Women Against State Pension Inequality (WASPI) movement in the UK. The latter organization does not fight the rise in retirement age as such, but does not agree with the way the changes were implemented-with little/no personal notice, faster than promised, and no time to make alternative plans (http://www.waspi.co.uk/).

As almost all industrialized countries are introducing policies to extend working lives it is imperative that we understand the psychosocial impact that this is having on older workers-notably those who are close to the previous State Pension Age. This article examines older workers' emotional reactions to rising retirement age. This is an important issue since, in addition to their influence on general well-being, emotions and emotional states have repercussions for the workplace, both behavioral and attitudinal (Elfenbein, 2007; Kiefer, 2002).

Emotions are a reaction to an event, indicating an episode of importance to the individual (Lazarus, 1991). The sudden policy changes that forced older employees to work longer can be viewed in this way. Events are cognitively appraised along different dimensions leading to different specific emotions, such as anger and fear or worry, but also happiness and joy. Individuals appraise events according to their individual goals, to their beliefs and values and in the light of 
their own potential for coping with the situation (Lazarus, 1991). This implies that individuals may vary in their emotional reactions to the rising retirement age and that the individual's access to resources play an important role in this respect. We focus on two different types of emotional reactions: anger about the reforms, and worry on the part of the individual worker, who may not have a sense that they will be able to endure-physically and mentally-in their job till their retirement age.

This article contributes to the literature in three ways. This study is - to our knowledge - the first that examines older workers' emotional reactions to reforms that induce them to extend their working lives with a number of years. There is a clear need to deepen our understanding of older workers' affective reactions when faced with a shift in the retirement age. Emotions, and negative emotions in particular-may have negative consequences for well-being and performance at work (Fisher, Ryan, Sonnega, \& Naudé, 2016) and this may indicate a lack of individual agency in the retirement process. Second, this study combines theoretical insights from research on emotions (Lazarus, 1991) with the resource-based perspective (Wang et al., 2011). Given that a rising retirement age significantly alters retirement prospects and thereby adjustment to the retirement transition, it is assumed that older workers' access to resources influence how they emotionally react to rising retirement age. Based on these two theoretical approaches, we formulate hypotheses why pension reforms trigger stronger emotional reactions in some individuals than in others, and which factors play a role in this respect. Linking older workers' resources to their emotional reactions to rising retirement age is novel and may help to unpack the black box on how older adults form their reactions to retirement-related policies. Third, in order to study older adults' emotional responses to the retirement reforms, we collected data among a large sample of wage employed older workers aged 60 to 65 years in the Netherlands. Precisely this cohort is the first that has to deal with a retirement age that is much higher than before. The Netherlands may be particularly interesting, since the reforms have been implemented in a relatively short time window, and faster than originally communicated.

We begin this article with an overview of our theoretical framework for understanding older adults' emotional reaction to rising retirement age. After discussing the methods, we present results from the first wave (conducted in 2015) of the Netherlands Interdisciplinary Demographic Institute (NIDI) Pension Panel. This is a prospective cohort study among 6,800 wage employed older workers (60-65 at baseline) enrolled in three of the bigger Pension Funds in the Netherlands. We conclude with a discussion.

\section{THEORETICAL BACKGROUND AND HYPOTHESES}

Ekerdt et al. (2000) have shown that anticipatory engagement with retirement often starts many years in advance. In this process, older workers develop increasingly concrete plans and goals for retirement. This may go in tandem with a process of disengagement from the work role in anticipation of retirement (Damman et al., 2013). The recent retirement reforms, that have been implemented in many developed countries, generally leave older workers with few opportunities for agency regarding their retirement timing, and may thus have blocked the plans for retirement for many older workers.
This article examines older workers' emotional reaction to the pension reforms. The rise in retirement age is an event or episode that may be perceived to be a threat in relation to the attainment of personal goals. Lazarus (1991) has argued that the appraisal or interpretation of an event leads to emotions and affective responses, and not the event per se. Central elements in this appraisal are the perceived goal obstruction and the individual's evaluation of his/her own potential for coping with the situation at hand. Although Lazarus theory of emotion provides a general framework for studying older workers' emotional reactions to the rising retirement age and inter-individual variation in these emotions, it offers few concrete hypotheses about how the various forces explain how individuals are being emotionally effected by the reforms. Therefore, we combine insights of the theory of emotion (Lazarus, 1991) with insights from the resource-based perspective (Wang et al., 2011) which emphasizes that resources are important in fulfilling one's central valued needs and that the individual's access to resources impact how they adjust into significant life transitions. Linking older workers' resources to their emotional reactions to rising retirement age may help to increase our understanding of how older adults form their reactions to retirement-related policy changes. We focus on two different types of emotional reactions: anger and worry. First, the changes in the pension arrangements may have blocked older workers' plans for retirement. Anger and frustration are emotions that occur in situations where a person is blocked from reaching a desired outcome or goal. Second, the prospect of extending working live may evoke worry concerning one's capability to endure-physically or mentally-in the job till the new retirement age.

Access to resources may mitigate or neutralize the negative consequences of an event. Following this line of argument, we assume that working longer is more challenging - and may thus give rise to stronger emotional reactions - whenever job demands are high, and personal, work and nonwork resources are limited. We will elaborate on these factors subsequently.

\section{Personal Resources}

Poor health affects workability (Koolhaas et al., 2014). Health limitations in the workplace are a major reason for retiring (Van den Berg et al., 2010). Health may be at odds with prolonged labor market activities. Older workers may feel insecure and have worries about their ability to keep up in the job till their retirement age. This insecurity may cause stress at work and anger about the reforms. Apart from health issues that limit the workability, chronic health conditions may also impact the preferences for leisure (Camerino et al., 2008). Chronic health conditions may negatively impact life expectancy and perceptions of life expectancy and increase a preference for leisure among older workers (Van Solinge \& Henkens, 2010). This is acknowledged in the following hypothesis:

Hypothesis 1: Chronic health condition and health limitation at work are positively associated with (a) anger, (b) worry to endure physically, and (c) worry to endure mentally.

Financial resources play an important role in the retirement decision making process. Empirically research has consistently shown a positive effect of financial resources on retirement. Individuals with greater 
accumulated wealth have a greater probability of retirement (Fisher, Chaffee, \& Sonnega, 2016). This suggests that financial resources, wealth in particular, may increase older adults' opportunities for agency in the retirement process. Financial resources may thus allow older workers to play a more active role in designing their retirement, even in the light of existing constraints (e.g., rising retirement age). Given that financial resources offer individuals more opportunities to leave the labor force whenever working is too stressful or demanding, we assume the following:

\section{Hypothesis 2: Financial resources are negatively associated with (a) anger, (b) worry to endure physically, and (c) worry to endure mentally.}

\section{Work-Related Resources}

Conditions at work play an important role in turnover intentions (e.g., Cottini et al., 2011) as well as in retirement decision making (e.g., Brussig, 2016; Mortelmans \& Vannieuwenhuyze, 2013; Van Solinge \& Henkens, 2014). Conditions at work may thus be important as well when it comes to extending working live. We assume that extending working life is more challenging in jobs where the balance between demand and resource (e.g., Bakker \& Demerouti, 2007) is less favorable. This is deemed to be the case in lower class jobs. These jobs are characterized by lower skill levels, less work autonomy and harsher working conditions compared to higher class jobs. Higher and lower professionals may have a more stressful job in terms of responsibility, supervising and workload, but their jobs are also less physically demanding and offer more possibilities for autonomy (Erikson \& Goldthorpe, 1992).

\section{Hypothesis 3: Older workers in lower social/occupational classes and (unskilled) manual workers, in particular are more likely (a) to be angry, and (b) to worry about their ability to endure physically and (c) less likely to worry about their ability to endure mentally in their jobs compared to older workers belonging to the higher occupational classes.}

Individual circumstances of working life may vary between older workers within the same occupational category. The extent to which extending one's working life is more challenging may also depend on the duration (working hours, career length) and patterns of exposure (shift or irregular work) to physical and mental working conditions.

Work-life, including adverse working conditions, is a potential source of poor health and disparities in health. Individuals work many hours over their life, so their cumulative exposure to working conditions can be an important source of health disparities (Fletcher et al., 2011). Given that the effects of physical and mental work demands may accumulate over time, we assume that older workers are more likely to worry about their ability to endure physically and mentally to the extent that they have longer working career. In addition to this cumulative health mechanism, socio-normative mechanism may also play a role in the relationship between emotional reactions to rising retirement age and career duration. Individuals have perceptions about the appropriate retirement age and these perceptions affect their retirement preferences and decisions (Feldman \& Beehr, 2011). In the Netherlands, societal standards regarding normative career duration seem closely tied with the fact that till very recently, full occupational pension eligibility was based on 40 years of contribution. Many retirement schemes offered opportunities to retire after 40 years in the labor force. This is history now. Current cohorts of older workers may end up with working careers that last 45-50 years. Individuals may, however, still have a firm belief that " 40 years of work is enough." In line with the health and socio-normative arguments, we assume that:

$$
\begin{aligned}
& \text { Hypothesis 4: Career duration is positively associated with (a) } \\
& \text { anger, (b) worry to endure physically, and (c) } \\
& \text { worry to endure mentally. }
\end{aligned}
$$

The potential role of part-time work in the context of the "Active Ageing" strategy has been highlighted in many policy documents (Kullmann \& Rocca, 2016). The underlying idea is that the final exit from the workforce can be postponed, by decreasing the employee's workload. In addition, part-time work enables older adults to better organize their work and private lives in the light of care responsibilities (Ebbinghaus, 2006). We assume that:

\section{Hypothesis 5: Part-time work, or combining part-time work with part-time retirement, is negatively associated with (a) anger, (b) worry to endure physically, and (c) worry to endure mentally.}

Research on the impact of nonstandard working arrangements (e.g., shift and night work) on health reveal that nonstandard working patterns are linked with health problems and stress, and seemingly more so in older workers (Costa, 2003). Aging may be associated with a progressive intolerance to shift work due to reduced psycho-physical fitness, the decreased restorative properties of sleep, and higher proneness to desynchronization of biological rhythms (Costa \& Di Milia, 2008). In addition, people engaged in shift and night work are frequently out of phase with society, this may interfere with the coordination of family time tables and duties. As such we assume that extending working life is more challenging for older workers with nonstandard working hours. We assume that:

$$
\begin{aligned}
& \text { Hypothesis 6: Nonstandard working hours / shift work is } \\
& \text { positively associated with (a) anger, (b) worry } \\
& \text { to endure physically, and (c) worry to endure } \\
& \text { mentally. }
\end{aligned}
$$

\section{Nonwork-Related Factors}

A large body of research points to the importance of the family context for understanding work and retirement decisions. Research has shown that behavior, opinions and needs of significant others in the older adult's social network play a role in the retirement process (for an overview: Matthews \& Fisher, 2013). In order to understand the role of family factors in extending working life, we make a distinction between family demands and resources. Family demands, defined as aspects in the family domain that require sustained physical and/or mental effort, may drain the employee's personal resources, or at least place them at risk to become overburdened (Peeters et al., 2005). Overburdened 
workers are likely to function sub-optimally in the work role (Edwards \& Rothbard, 2000). The more family commitments a person has, the greater are the time demands from the family domain, which limit his or her capacity to accommodate work demands. Caregiving for older, sick, or disabled family members may be particularly demanding and interfering with work requirements. We therefore assume that:

Hypothesis 7: Caregiving is positively associated with (a) anger, (b) worry to endure physically, and (c) worry to endure mentally.

Family members may be a resource as well. Greenhaus and Powell (2006) have described the theoretical mechanism that enable work and family to benefit from each other. This has been called work-family enhancement. Work-family research has been dominated for a long time by empirical inquiry into work-family conflict (Barnett, 1998). There is, however, growing evidence within this literature, that the work-family interface can also result in synergies, or "positive spillover" between work and family (Geurts \& Demerouti, 2003). Previous research points to the potential support provided by partners in demanding work conditions (Bianchi \& Milkie, 2010) and adjustment to the retirement transition (Van Solinge \& Henkens, 2005). Henkens (1999) has shown that the partner's attitudes towards work-retirement play a role in retirement decision making. Older workers whose partner does not support extending working life want to retire earlier, than workers whose partner supports staying in the workforce. Given that partners may be a source of social support, companionship and help, we assume that:

Hypothesis 8: Partner support for extending working life is negatively associated with (a) anger, (b) worry to endure physically, and (c) worry to endure mentally.

\section{METHOD}

Data

This article is based on the first wave of the NIDI Pension Panel. This is a prospective cohort study among wage employed older workers (6065 at baseline) enrolled in three of the bigger Pension Funds in the Netherlands. The funds represent the following sectors: Civil Servants, Education, Care, Welfare, and Construction.

The data for this first wave have been collected in the period MayNovember 2015. Future waves are envisaged for 2018 and 2021. The study used a stratified design. In a first step, a sample has been drawn from the various organizations covered by one of the three larger pension funds in Netherlands (ABP and PfZW, BpBouw). These three pension funds represent approximately $48 \%$ of wage employed workers in the Netherlands (DNB, 2015). In a next step, within the selected organizations, a random sample was drawn from the population older workers aged 60 years and over (birth cohorts 1950-1955) who worked at least $12 \mathrm{hr}$ a week.

The selected older workers received a mailing of their pension fund on their postal address. The mailing consisted of a questionnaire for the employee and a questionnaire for the partner (if applicable) with an accompanying letter from a representative of the Pension Fund and also a cover letter of the researchers. Respondents were offered the choice to use the written questionnaire, or to fill in an online questionnaire. In total of 15,496 questionnaires were mailed out, of which 6,800 questionnaires were returned (net response rate: 44\%). Item nonresponse on the independent variables was low (on average, less than $3 \%$ ). Under these circumstances, less rigorous missing data procedures than multiple imputation (MI) are generally acceptable (Little et al., 2014). We therefore dealt with missing data on the explanatory variables by single stochastic regression imputation (Enders, 2010). Cases with missing data on the dependent variables have been excluded from the analysis.

The analyses presented in this article are based on a sub-sample of older workers born between 1951 and 1955 . The 1950 cohort was excluded since many of them retired during the data collection period, whereas others are very close to State Pension Age and possibly in anticipation of their retirement already. In addition, a small proportion of the sample has received a shorter version of the questionnaire, that did not include the questions on anger and worry. These individuals $(N=498)$ have been removed from the analytical sample as well. As a result, the base sample for the analyses consists of 5,700 workers aged 60-64 years. Comparing the analytical sample with the original sample reveals differential response rates for sub-categories. The oldest cohort has a higher response rate (45\%) than the youngest cohort (42\%), and women (50\%) have higher response rates than men (43\%). There are also differences across sectors. Construction workers and Social workers have lower response (40\%) rates than workers in the other sectors $(47 \%)$. There are no significant differences in response rates for workers in small, medium and large organizations. Comparing the analytical sample with the total waged-employed population in the age bracket, reveals that women, oldest cohorts and higher educated persons are overrepresented. Particularly, the educational level in the sample is relatively high: $47 \%$ has a higher education, against $30 \%$ in the total population of workers in the same age bracket. The proportion with lower education (20\%) is low compared to that in the total population (32\%).

The participants in this study, all of whom were born between 1951 and 1955 on average expect to retire at age $65.8(S D=1.5)$. This is already considerably higher than the previously fixed State Pension Age of 65, and much higher than the average effective retirement age of around 60 for previous cohorts (CBS, 2016). If they had a say in matters, the participants would want to retire on average at age 63.3 $(S D=2.2)$. This is 2.5 years earlier than they actually expect to retire. The vast majority $(86 \%)$ of older workers in the sample has to work till (considerable) later ages than anticipated or desired. Nine percent do not have a time-lag, whereas $5 \%$ actually has a preference for later retirement. The variation in the preferred retirement age is substantially greater than in the planned retirement age.

\section{Measures}

Study variable

We study older adults' emotional reactions to rising retirement age. We focus on two emotions: anger about the reforms and worries about surviving in the job. Older workers' emotions have been assessed with the following question with five response options $(1=$ extremely to $5=$ not at all, reverse coded): "Retirement ages have increased rapidly. Because of this, to what extent do you feel angry?". In addition, participants were asked about their worry regarding surviving in their jobs by 
means of two questions with five response options $(1=$ extremely to $5=$ not at all, reverse coded): "To what extent do you experience the following issues because of the higher retirement ages.... Worry whether I can keep up physically in my job, and .... worry whether I can keep up mentally in my job. All items as well as their means are listed in Table 1.

\section{Personal factors}

Health status is assessed with two variables. The number of chronic conditions is derived from a 12-category questionnaire-based inventory of 12 diagnosed longstanding diseases, conditions and handicaps as diagnoses by a doctor (Koppes et al., 2009). Limitations at work is a threecategory variable indicating to what extent (not, slightly, and strongly) health conditions limit performance at work. Financial resources are assessed with one variable. Wealth is a seven-category variable indicating total accumulated wealth (housing, assets and bank balances, and cash).

Work-related factors

Work context is captured by four variables. Occupational Class is nine-category questionnaire-based occupational classification developed by Ganzeboom (De Vries \& Ganzeboom, 2008). The classification is based on the EGP social class scheme (Erikson \& Goldthorpe, 1992). We distinguish eight classes: (1) higher level professionals, (2) higher level managers, (3) lower level professionals, (4) lower level managers, (5) clerical routine, sales and services nonmanual workers, (6) skilled manual workers and manual supervisors, (7) semi-skilled manual workers, (8) unskilled manual workers. Given their small number $(N=10)$ agricultural workers (class 9$)$ have been categorized as semi-skilled manual workers (class 7). Working hours is based on the usual number of weekly working hours in the main job. We distinguish three categories: working full-time (more than $36 \mathrm{hr}$ a week), working part-time (less than $36 \mathrm{hr}$ a week). Part-time workers are divided into those who have reduced working hours in the past 5 years, and those who did not reduce working hours in the past 5 years. Note that the Netherlands has traditionally a large share of workers who are in parttime employment for most of their career. Working unusual hours is a dummy variable that takes value one if the older worker has worked (at the workplace) in the evening or during night-time in the past 30 days. Duration of labor market career is based on the workers' age at interview, his/her age upon first entry in the labor market and interruptions in the career (if any).

\section{Family-related factors}

Family context is captured with two variables. Caregiving responsibilities is a dummy variable coded one if the older worker provides personal care to members inside or outside his/her household. The measure for partner support is based on marital status and a question on perceived partner support for extending working life: "Would your partner support working beyond State Pension Age (for 1 day a week)?” ( 1 = not at all, $5=$ very $m u c h$ ). We distinguish three categories: people without a partner is the reference category. One dummy variable indicates those older worker with a high partner support for extending working life (answer categories 4 and 5). A second dummy variable indicated those older workers with a low partner support for extending working life.

\section{Control variables}

Time to State Pension Age is calculated on the basis of administrative data on birth year and month and State Pension eligibility. Gender is a dummy coded one if the older worker is male. Sector indicates in which sector the older worker is employed. We distinguish five sectors: Civil Servants, Education, Construction, Care, and Social Work. The information on Time to State Pension Age as well as Sector has been derived from the Administrative Records of the Pension Funds.

Table 1 presents the percentages, means, SDs, coding and wording of the survey questions of the measures for the independent variables.

\section{Qualitative data}

To deepen the understanding of the challenges older workers face when confronted with the rising retirement age, we used qualitative data from an open-ended question on the back of the questionnaire, where participants were invited to share their personal experiences and opinions regarding work and retirement.

\section{Analysis}

We first provide some descriptive statistics and qualitative data. Second, we perform a multivariate analysis. Ordinary least square (OLS) regression is used to determine the conditions under which older workers express stronger emotional reactions to rising retirement age. To deal with multi-level structure of the data (older workers in three pension funds who are nested in organizations), standard errors that allow for intra-departmental correlation were used in the analyses (STATA command Cluster). Sector dummies were included in the models to control for potential sector-level effects. All analyses were performed using Stata 14 statistical package.

In order to be able to compare the effects sizes of the predictor variables, we standardized the dependent variables (mean $=0, S D=1)$ to obtain effect sizes in terms of Cohen's $d$ for the dummy variables in the analyses In the tabular presentations of results, coefficients and SDs are shown (Table 3).

\section{RESULTS}

\section{Descriptive Results}

The results in Table 2 suggest that the reforms had their repercussions. Many older workers feel they have been done a great injustice: $45 \%$ of all participants are very or extremely angry about the later retirement age. This proportion is substantially higher than the share of older workers who experience little $(15 \%)$ of no anger at all $(17 \%)$. Only a very small minority $(3 \%)$ is happy about the reforms. The great number of spontaneous comments on the back of the questionnaires illustrate older workers' frustrations with the increasing retirement age. Lot of the frustrations have to do with how the reforms have been implemented. A 60-year-old teacher says: "I do understand that the retirement age had to go up, but the way this is organized makes me very angry." People feel that retirement has become a moving target. This is clearly illustrated by the comments of a 62-year-old facility manager who states "I work uninterrupted from age 17 onwards. Initially, I could retire at age 61 . That has been increased to 62 , then to 65 , and now to 66 years. To be honest, I am fed up with this" and a 62-year-old engine driver "I am outraged by the haggling with my pension! My state pension age has changed three times within 2 years. Mismanagement!!!”. As a result of the changes that have taken place in quick succession people may experience a lack of control, as illustrated by the words of a 63-year-old social worker "I have the feeling that I do not have any agency with regard to my retirement, I do not feel in control of my 
Table 1. Descriptive Statistics, Wording and Coding of Predictor Variables

\begin{tabular}{|c|c|c|c|}
\hline Variable & Mean/\% & $S D$ & Wording, Coding and Psychometric Properties \\
\hline Years to State Pension Age & 4.7 & 1.9 & $\begin{array}{l}\text { Calculation on the basis of administrative data on birth year and month \& } \\
\text { State Pension Eligibility (range } 0-7 \text { ) }\end{array}$ \\
\hline Gender $($ male $=1)$ & 55 & & Dummy variable $($ male $=1)$ \\
\hline Number of chronicle conditions & 1.5 & 1.5 & \\
\hline 0 (reference group) & 31 & & Q: Do you have one or more of the following longstanding diseases, \\
\hline $1-2$ & 47 & & conditions, or handicaps (diagnosed by a doctor)? List of 12 conditions. \\
\hline $3-4$ & 18 & & Based on Nationale Enquête Arbeidsomstandigheden (NEA).Sum of \\
\hline 5 or more & 4 & & conditions (range $0-8$ ) \\
\hline \multicolumn{4}{|l|}{ Do conditions limit work performance? } \\
\hline No (reference group) & 57 & & Q: Do these conditions limit your performance at work? $1=I$ do not have \\
\hline Slightly & 34 & & health problems, $2=$ strongly limited, $3=$ slightly limited, $4=$ not limited \\
\hline Strongly & 9 & & \\
\hline Wealth & 4.1 & 1.8 & $\begin{array}{l}\text { Q: How large do you estimate your total wealth (own house, savings, stocks, } \\
\text { etc. minus debts/mortgage) to be? Seven-category classification, ranging } \\
\text { from } 1 \text { (less than 5,000 euros) to } 7 \text { (more than } 500 \text { thousand euros) }\end{array}$ \\
\hline \multicolumn{4}{|l|}{ Occupational class } \\
\hline Higher level professionals & 8 & & Q: In which category could your job or profession be grouped? Nine- \\
\hline Higher level managers (reference category) & 11 & & category occupational classifications developed by Ganzeboom. \\
\hline Lower level professionals & 36 & & \\
\hline Lower level managers & 7 & & \\
\hline $\begin{array}{l}\text { Clerical routine, sales and services } \\
\text { nonmanual workers }\end{array}$ & 18 & & \\
\hline Skilled manual work/manual supervisors & 5 & & \\
\hline Semi-skilled manual work & 12 & & \\
\hline Unskilled manual work & 3 & & \\
\hline \multicolumn{4}{|l|}{ Sector } \\
\hline Civil servants (reference category) & 24 & & Administrative data from Pension Funds \\
\hline Education & 22 & & \\
\hline Construction & 22 & & \\
\hline Care & 14 & & \\
\hline Social work & 18 & & \\
\hline Unusual working hours (yes = 1) & 23 & & Q: Did you ever work in the evening or at night, during the last 30 days? \\
\hline \multicolumn{4}{|l|}{ Working hours } \\
\hline Full-time (reference category) & 46 & & Q: How many hours a week do you work (excluding overtime)? \\
\hline Part-time & 38 & & Q: Do you intend to reduce the number of work hours when you get close \\
\hline Part-time work/ part-time retired & 16 & & $\begin{array}{l}\text { to your state pension age? }(1=\text { no, } 2=\text { do not know, } 3=I \text { am already doing } \\
\text { this, } 4=\text { yes I intend to work ... hrs less). Three category-variable: full-time } \\
\text { (more than } 36 \mathrm{hr} \text { ), part-time (less than } 36 \mathrm{hr} \text { ), part-time work/retired } \\
\text { (less than } 36 \mathrm{hr} \text {, and has reduced working hours). }\end{array}$ \\
\hline Number of years in labor force at interview & 39.1 & 6.3 & \\
\hline Less than 30 (reference category) & 8 & & Q: At what age did you start working? \\
\hline $30-34$ & 11 & & Q: Have you temporarily stopped working for more than 1 year after that? If \\
\hline $35-39$ & 29 & & yes, for how many years in total? (range 4-50) \\
\hline $40-44$ & 32 & & \\
\hline 45 or more & 20 & & \\
\hline \multicolumn{4}{|l|}{ Partner support for extending working life } \\
\hline No partner (reference category) & 18 & & Q: Do you have a partner? \\
\hline Partner: low support & 57 & & Q: Would your partner support working beyond State Pension Age (for \\
\hline Partner: high support & 24 & & 1 day a week $) ?(1=$ not at all, $5=$ very $m u c h)$ \\
\hline Care responsibilities (yes $=1$ ) & 15 & & $\begin{array}{l}\text { Q: Do you provide personal care/nursing to family members or friends who } \\
\text { are ill or in need of help? }\end{array}$ \\
\hline
\end{tabular}


Table 2. Descriptive Statistics of the Dependent Variables

\begin{tabular}{|c|c|c|c|}
\hline & $\%$ & Mean & $S D$ \\
\hline \multicolumn{4}{|l|}{ Retirement ages have increased rapidly. } \\
\hline $\begin{array}{l}\text { Because of this, to what extent do you feel } \\
\text { angry? (1-5) }\end{array}$ & & 3.3 & 1.4 \\
\hline Not at all & 16 & & \\
\hline A little & 15 & & \\
\hline Rather & 23 & & \\
\hline Very much & 18 & & \\
\hline Extremely & 28 & & \\
\hline \multicolumn{4}{|c|}{$\begin{array}{l}\text { Retirement ages have increased rapidly. Because of this, to what extent } \\
\text { do you feel happy? }(1-5)\end{array}$} \\
\hline Not at all & 80 & 1.3 & 0.7 \\
\hline A little & 13 & & \\
\hline Rather & 5 & & \\
\hline Very much & 2 & & \\
\hline Extremely & 1 & & \\
\hline \multicolumn{4}{|c|}{$\begin{array}{l}\text { To what extent do you experience the following issues because of the } \\
\text { higher retirement ages.... }\end{array}$} \\
\hline $\begin{array}{l}\text {.... worry whether I can keep up physically in } \\
\text { my job (1-5) }\end{array}$ & & 3.1 & 1.3 \\
\hline Not at all & 14 & & \\
\hline A little & 20 & & \\
\hline Rather & 26 & & \\
\hline Very much & 20 & & \\
\hline Extremely & 20 & & \\
\hline $\begin{array}{l}\text {....worry whether I can keep up mentally in } \\
\text { my job }(1-5)\end{array}$ & & 2.9 & 1.3 \\
\hline Not at all & 18 & & \\
\hline A little & 22 & & \\
\hline Rather & 27 & & \\
\hline Very much & 19 & & \\
\hline Extremely & 14 & & \\
\hline
\end{tabular}

life anymore." Many older workers doubt whether they will be able to continue working till their new retirement age. A 64-year-old truck driver states: "I find it outrageous that the retirement age is raised continuously. I have a lot of problems with my shoulders and neck." The figures in Table 2 underline that a large proportion of $60+$ workers is very $(20 \%)$ or extremely $(20 \%)$ worried that they cannot keep up with their work physically. Only one third of the respondents indicate that they have little $(20 \%)$ or no worries at all (14\%) in this respect. A similar picture emerges when it comes to worries about keeping up mentally, though the proportion that is very or extremely worried $(32 \%)$ is little lower.

\section{Multivariate Analyses}

Table 3 presents the results of the OLS regression model, with anger and worry about one's ability to keep up physically and mentally in the job as the dependent variable.

In Model 1-3 anger and worry about surviving physically and mentally in the job is regressed on personal, work-related and family-related factors. With regard to the personal factors, the results show that health and wealth are related to older workers' emotional reactions to rising retirement age in the expected direction. As predicted in Hypothesis
1, workers are more likely to be angry and to worry about their ability to keep up physically and mentally in their jobs to the extent that they have more chronically health conditions, and to the extent that they feel that their conditions more strongly limit their work performance. As predicted in Hypothesis 2, financial resources are negatively associated with anger and worry. Older workers with greater accumulated wealth (housing and [liquid] assets) are less likely to be angry and to worry about their ability to keep up physically and mentally in their jobs.

With regard to work-related factors, we found support for Hypothesis $3 \mathrm{a}-\mathrm{b}$, that older workers in more demanding jobs (those in the lower occupational classes and manual workers, in particular) are more angry and more likely to worry about their ability to keep up physically in their jobs compared to older workers belonging to the higher occupational classes. In contrast, we did not find clear support for Hypothesis 3c, that that older workers in the lower occupational classes and manual workers, in particular are less worried about their ability to keep up mentally in their jobs compared to older workers belonging to the higher occupational classes. In fact, worry about surviving mentally is most prominent among lower level professionals. This category includes teachers and nurses.

In addition to occupational class, we examined the relationship between emotions regarding rising retirement age and exposure to the demands of working life. The results show that only one of the indicators-career duration-is related to individual's emotional reactions to rising retirement age in the expected direction. As predicted in Hypothesis 4, workers are more likely to be angry and to worry about their ability to keep up physically and mentally in their jobs to the extent that they have longer career duration. Older workers who, at time of interview, stayed in the labor force for 40 years or more are more angry about the reforms and have much more worry regarding survival (both physically and mentally). We did not find strong support for Hypothesis 5 that part-time work is negatively associated with anger and worry to endure physically or mentally in the job. Compared to full-time workers, part-time workers were not less likely to show anger or worry concerning surviving physically. We did found an association between being part-time retired and worry to endure mentally, but this association was in the opposite direction. Compared to full-time workers, part-time retired workers are more likely to worry about surviving mentally in the job. Hypothesis 6 was partly confirmed. Older workers with unusual working hours/shift work are more likely to worry about surviving physically in their job than older workers with regular working hours. No effects were found for worry about surviving mentally and for anger.

With regard to family factors, we found partial support for Hypothesis 7 that caregiving is positively associated with anger and worry. The results show that older adults with caregiving responsibilities have more worry about their ability to keep up mentally in the job (Hypothesis 7c). The results do not support Hypothesis 7a-b that caregivers compared to non-caregivers are more likely to be angry or to worry about their ability to keep up physically in the job. Finally, we found support for our hypothesis that partner support matters with regard to extending working life (Hypothesis 8). Older workers whose partner does support extending working life are less likely to be angry and less likely to worry about their ability to keep up mentally compared to single workers. Older workers whose partner is not supporting extending working life, are more likely to be angry about the reforms. 
Table 3. Results of OLS Regression Explaining Emotional Reactions to Rising Retirement Age

\begin{tabular}{|c|c|c|c|c|c|c|}
\hline & \multicolumn{2}{|l|}{ Anger } & \multicolumn{2}{|c|}{$\begin{array}{l}\text { Worry Enduring } \\
\text { Physically }\end{array}$} & \multicolumn{2}{|c|}{$\begin{array}{l}\text { Worry Enduring } \\
\text { Mentally }\end{array}$} \\
\hline & Coef. & $S D$ & Coef. & $S D$ & Coef. & $S D$ \\
\hline \multicolumn{7}{|l|}{ Personal factors } \\
\hline Yrs to State Pension Age & $0.08^{* *}$ & 0.007 & $0.09^{* *}$ & 0.007 & $0.10^{* *}$ & 0.007 \\
\hline Gender $($ male $=1)$ & $0.12^{* *}$ & 0.035 & $-0.21^{* *}$ & 0.035 & -0.07 & 0.036 \\
\hline \multicolumn{7}{|l|}{ Number of chronic conditions (none = ref.) } \\
\hline $1-2$ & $0.12^{* *}$ & 0.033 & $0.14^{* *}$ & 0.032 & $0.07^{*}$ & 0.034 \\
\hline $3-4$ & $0.24^{* *}$ & 0.045 & $0.38^{* *}$ & 0.040 & $0.20^{* *}$ & 0.047 \\
\hline 5 or more & $0.32^{* *}$ & 0.072 & $0.54^{* *}$ & 0.060 & $0.31^{* *}$ & 0.074 \\
\hline \multicolumn{7}{|l|}{ Do conditions limit work performance? (not $=$ ref.) } \\
\hline Slightly & $0.16^{* *}$ & 0.033 & $0.42^{* *}$ & 0.031 & $0.31^{* *}$ & 0.034 \\
\hline Strongly & $0.39^{* *}$ & 0.050 & $0.85^{* *}$ & 0.044 & $0.58^{* *}$ & 0.054 \\
\hline Wealth & $-0.04^{* *}$ & 0.007 & $-0.04^{* *}$ & 0.007 & $-0.02^{* *}$ & 0.009 \\
\hline \multicolumn{7}{|l|}{ Work-related factors } \\
\hline \multicolumn{7}{|l|}{ Occupational class (higher level managers $=$ ref. $)$} \\
\hline Higher level professionals & $-0.13^{*}$ & 0.063 & -0.00 & 0.055 & -0.04 & 0.061 \\
\hline Lower level professionals & $0.20^{* *}$ & 0.048 & $0.19^{* *}$ & 0.041 & $0.18^{* *}$ & 0.046 \\
\hline Lower level managers & $0.12^{* *}$ & 0.064 & $0.12^{*}$ & 0.056 & 0.11 & 0.062 \\
\hline $\begin{array}{l}\text { Clerical routine, sales and services nonmanual } \\
\text { workers }\end{array}$ & 0.24 & 0.055 & $0.11^{*}$ & 0.048 & 0.06 & 0.053 \\
\hline Skilled manual work/manual supervisors & $0.35^{* *}$ & 0.063 & $0.41^{* *}$ & 0.064 & -0.13 & 0.075 \\
\hline Semi-skilled manual work & $0.44^{* *}$ & 0.060 & $0.52^{* *}$ & 0.052 & -0.07 & 0.064 \\
\hline Unskilled manual work & $0.52^{* *}$ & 0.082 & $0.52^{* *}$ & 0.085 & 0.01 & 0.092 \\
\hline \multicolumn{7}{|l|}{ Working hours (full-time = ref.) } \\
\hline Part-time & -0.05 & 0.038 & -0.03 & 0.033 & -0.05 & 0.036 \\
\hline Part-time retired & -0.06 & 0.037 & 0.03 & 0.033 & $0.08^{*}$ & 0.037 \\
\hline Unusual working hours & -0.00 & 0.032 & $0.09^{* *}$ & 0.029 & 0.02 & 0.033 \\
\hline \multicolumn{7}{|l|}{ Length of occupational career (less than $30=$ ref.) } \\
\hline $30-34$ & 0.05 & 0.065 & -0.02 & 0.054 & 0.02 & 0.058 \\
\hline $35-39$ & 0.10 & 0.055 & 0.03 & 0.046 & $0.11^{*}$ & 0.052 \\
\hline $40-44$ & $0.32^{* *}$ & 0.056 & $0.15^{* *}$ & 0.048 & $0.18^{* *}$ & 0.054 \\
\hline 45 or more & $0.46^{* *}$ & 0.066 & $0.21^{* *}$ & 0.061 & $0.32^{* *}$ & 0.070 \\
\hline \multicolumn{7}{|l|}{ Family-related factors } \\
\hline Care responsibilities & 0.06 & 0.035 & 0.04 & 0.034 & $0.08^{*}$ & 0.034 \\
\hline \multicolumn{7}{|l|}{ Partner support for working longer (no partner $=$ ref.) } \\
\hline Partner: low support & $0.14^{* *}$ & 0.037 & 0.04 & 0.032 & 0.06 & 0.037 \\
\hline Partner: high support & $-0.11^{* *}$ & 0.041 & -0.06 & 0.036 & $-0.09^{*}$ & 0.041 \\
\hline Observations & 5,122 & & 5,354 & & 5,098 & \\
\hline$R^{2}$ & 0.18 & & 0.29 & & 0.14 & \\
\hline
\end{tabular}

Note. Models are controlled for Sector. OLS = ordinary least square.

${ }^{*} p<.05 .{ }^{* *} p<.01$.

We did not find a significant association between partner support and worry about surviving physically.

With respect to gender, the analysis reveal some interesting findings. Men tend to be more angry than women about the reforms, whereas women experience more worry about their ability to keep up physically in the job. The latter may have to do with "the double burden": the fact that in heterosexual couples where both partners have paid jobs, women often spend significantly more time than men on household chores and caring work, such as childrearing or caring for sick family members. This phenomenon is also known as "The Second Shift" (Hochschild \& Machung, 2012).

\section{DISCUSSION}

All over the world the retirement landscape is changing radically. Probably one of the bigger and more fundamental changes is the rise in the pension eligibility age. In most countries, this age had not increased above 65 years since its inception in the first half of the 20th century. The fact that these reforms came very quickly after the closing of early retirement opportunities urged the large pre-pension cohorts to adjust their retirement outlooks. This was definitely the case in the Netherlands, where the new pension rules came into effect in less than 10 years. 
This research studied older workers' emotional reactions to reforms that induce them to extend their working lives with a number of years. Using data from a large scale sample survey among 6,800 older workers in the Netherlands, aged 60-65 at time of interview in 2015, we examined why the pension reforms trigger stronger emotional reactions in some individuals than in others. In the Netherlands, reforms have been implemented across the board but older adults may differ in their capability to extend their working lives and their agency to design their retirement in the light of existing constraints. Our study reveals that adjustment to the prospects of a longer working life may be less self-evident than often assumed in policy circles. In our sample a significant proportion (44\%) of older workers stated that they are very or even extremely angry about the increase in the retirement age. Furthermore, a large proportion of these $60+$ workers report high levels of worry about their ability to keep up with their job till retirement age, either physically or mentally.

This article integrated theoretical insights from the theory of emotion (Lazarus, 1991) and the resource-based perspective on retirement adjustment (Wang et al., 2011). Based on these theoretical approaches we showed that working longer is more challenging-and may thus give rise to stronger emotional reactions - whenever job demands are high, and personal, work and nonwork resources are limited to buffer the negative effects of high job demands. Anger and worry is more prevalent among older workers in more demanding jobs (individuals in lower occupational classes, and manual workers in particular, as well as older workers with long careers) and less personal (poor health conditions, less favorable financial positions) and social resources (lack of partner support).

\section{Contributions}

There are several noteworthy strengths of this study. This article is the first that examines how older workers emotionally experience the changes in the retirement regulations that induce them to extend their working lives and how this relates to inequality in individual's access to resources. This topic is of increasing importance in an area where new generations are likely to be confronted with constantly changing retirement rules and increasing retirement income uncertainty. Further, this study expanded the scope of the resource-based perspective-a theoretical approach for understanding retirement adjustment-to emotional reactions to a rising retirement age. Strong negative emotional reactions may indicate poor adjustment or adjustment problems (Lazarus, 1991; Monat \& Lazarus, 1991).

This study has practical implications for HR managers and policy makers. The I/O literature has shown that organizational change triggers emotional reactions and that these emotions may have consequences (in terms of behavior and attitudes) at the workplace (Elfenbein, 2007). Our study makes clear that older workers' emotional reactions to macro-level policy changes have repercussions in the workplace as well. A large part of the $60+$ workforce is frustrated about the rising retirement age, and they are at risk to disengage from work (Damman et al., 2013; Kiefer, 2005). The organizational change literature suggests that acknowledging emotions rather than trying to keep them down helps employees to manage change and to adjust to the requirements of their new situation (e.g., Kiefer, 2002). This implies that an understanding of and a proactive dealing with older workers' emotional reactions to rising retirement age is vital for HR-managers and employers. In this process, anger about the reforms may be treated differently from worry on the part of the older worker, who may not have the sense that he/she will be able to keep up (physically or mentally) in the job till their new retirement age.

It was to be foreseen that rising the retirement age is not a popular policy option. This study suggests that the public policy makers and politicians-mostly higher level professionals who are much less exposed to the challenges of working longer-may have underestimated the psychological and social impact of the reforms on vulnerable groups of older workers and, in particular, less educated, less healthy older workers with lower social status. With a further increase of retirement age to be expected, policy makers are challenged to design policies that spare vulnerable groups in particular, for example, by facilitating more flexibility in the transition into retirement. Further the pace in which different successive reforms are implemented may be questioned. The Dutch case clearly suggests that changing the rules of the game several times in a relatively short time span evokes strong negative emotions among the population.

\section{Limitations and Suggestions for Future Research}

When interpreting the study findings, some limitations should be kept in mind. First, this study is based on cross-sectional data. In cross-sectional studies, information on risk factors and outcomes as well as other factors, is obtained at the same time-point. This limits possibilities for causal inference. Using objective measures rather than subjective evaluations can help to avoid biases (Yu \& Tse, 2012). We therefore preferred structural predictors (occupational class) rather than self-reported evaluations (perceived job demands). New study rounds may offer researchers the opportunity to investigate the dynamic aspects of emotional reactions to a higher retirement age and show whether anger and worry decrease over time as individuals adapt to the requirements of their new situation, as assumed by Lazarus (1991). A second limitation relates to the generalizability of the study. Although the study is based on a random sample of wage employed older workers in more than 1,500 organizations covered by three of the biggest pension funds in the Netherlands, the sample is not representative for all older workers in the Netherlands. Some sectors and occupations are not included, and this holds for self-employed individuals as well. Our sample includes a larger proportion of higher educated older workers than the general population in the corresponding age bracket. As a result the prevalence of anger and worry may be somewhat underestimated.

Now that we have reviewed both theoretical and practical contributions of this study, we propose a few new research directions, based on the resource-based perspective, to help guide further theoretical and empirical examination of emotional reactions to rising retirement age/delaying retirement. First, most studies adopting the resourcebased perspective on adjustment to retirement have concentrated on a narrow set of resources, particularly health and wealth (Wang \& Shultz, 2010). This study employed a broader view and recognized the potential impact of the social network (family demands and resources) on emotional reactions to rising retirement age. Our results suggest that older workers can draw resources from the social environment in which they are embedded to facilitate adjustment to later retirement ages. One aspect of this social environment, the workplace, has received less attention so far. Given that employers play a crucial role in enabling extending working live (Conen et al., 2012), future research should particularly focus on the role of the organization in adjusting to 
rising retirement age. An interesting question — both from a scientific and societal point of view - is whether organizational climate buffers older worker's emotional reactions to rising retirement age. In other words: is adjustment to longer working lives easier in some organizations than is others?

Second, personality variables and dispositional traits have been shown to be important individual resources that influence adjustment quality in various types of life transitions and adjustment processes (Wang et al., 2011). Given that personality variables and dispositional traits are important for people in conducting emotional appraisals, setting up motivational priorities, and choosing coping strategies (Lazarus, 1991; Löckenhoff et al., 2009), future research should focus on explicating how these variables may influence older worker's emotional reactions to policy reforms that induce them to work longer and the as well as their adjustment to this new reality. Moreover, further theoretical advancement is possible by studying emotional reactions to exit from the work role.

\section{ACKNOWLEDGMENTS}

This article has been written during the authors' stay as a fellow at the Netherlands Institute for Advanced Study in the Humanities and Social Sciences (NIAS) in Wassenaar, The Netherlands (January-July 2016). This work was supported by the Netherlands Organization for Scientific Research NWO (VICI-grant 453-14-001 to K. Henkens). We thank the editor and the two anonymous reviewers for their valuable comments on earlier drafts of this manuscript.

\section{REFERENCES}

Bakker, A. B., \& Demerouti, E. (2007). The job demands-resources model: State of the art. Journal of Managerial Psychology, 22, 309-328.

Barnett, R. C. (1998). Toward a review and reconceptualization of the work/family literature. Genetic, Social, and General Psychology Monographs, 124, 125.

Bianchi, S. M., \& Milkie, M. A. (2010). Work and family research in the first decade of the 21st century. Journal of Marriage and Family, $72,705-725$.

Brussig, M. (2016). Working conditions in the last job and transitions into old-age pensions: An analysis of two pension entry cohorts in Germany. Work, Aging and Retirement, 2, 54-64.

Camerino, D., Conway, P. M., Estryn-Béhar, M., Costa, G., \& Hasselhorn, H.-M. (2008). Age-dependent relationships between work ability, thinking of quitting the job, and actual leaving among Italian nurses: a longitudinal study. International Journal of Nursing Studies, 45, 1645-1659.

CBS. (2016). Pensioenleeftijd voor negende jaar omhoog. Retrieved from https://www.cbs.nl/nl-nl/nieuws/2016/09/ pensioenleeftijd-voor-negende-jaar-omhoog

Conen, W. S., Henkens, K., \& Schippers, J. (2012). Employers' attitudes and actions towards the extension of working lives in Europe. International Journal of Manpower, 33, 648-665.

Costa, G. (2003). Shift work and occupational medicine: An overview. Occupational Medicine, 53, 83-88.

Costa, G., \& Di Milia, L. (2008). Aging and shift work: A complex problem to face. Chronobiology International, 25, 165-181.

Cottini, E., Kato, T., \& Westergaard-Nielsen, N. (2011). Adverse workplace conditions, high-involvement work practices and labor turnover: Evidence from Danish linked employer-employee data. Labour Economics, 18, 872-880.

Damman, M., Henkens, K., \& Kalmijn, M. (2013). Late-career work disengagement: The role of proximity to retirement and career experiences. Journals of Gerontology, Series B: Psychological Sciences and Social Sciences, 68, 455-463.

De Vries, J., \& Ganzeboom, H. B. G. (2008). Hoe meet ik beroep? Open en gesloten vragen naar beroep toegepast in status-verwervingsonderzoek. Mens \& Maatschappij, 83, 71-96.

DNB. (2015). Jaargegevens Individuele Pensioenfondsen 2015. Retrieved from De Nederlandsche Bank: https://www. dnb.nl/statistiek/statistieken-dnb/financiele-instellingen/ pensioenfondsen/gegevens-individuele-pensioenfondsen/ index.jsp

Ebbinghaus, B. (2006). Reforming early retirement in Europe, Japan and the USA. Oxford, UK: Oxford University Press.

Edwards, J. R., \& Rothbard, N. P. (2000). Mechanisms linking work and family: Clarifying the relationship between work and family constructs. Academy of Management Review, 25, 178-199.

Ekerdt, D. J., Kosloski, K., \& DeViney, S. (2000). The normative anticipation of retirement by older workers. Research on Aging, 22, 3-22.

Elfenbein, H. A. (2007). Emotion in organizations: A review and theoretical integration. The Academy of Management Annals, 1, 315-386.

Enders, C. K. (2010). Applied missing data analysis. New York, NY: Guilford Press.

Erikson, R., \& Goldthorpe, J. H. (1992). The constant flux: A study of class mobility in industrial societies. Oxford, UK: Clarendon Press..

Feldman, D. C., \& Beehr, T. A. (2011). A three-phase model of retirement. American Psychologist, 66, 193-203.

Fisher, G. G., Chaffee, D. S., \& Sonnega, A. (2016). Retirement timing: A review and recommendations for future research. Work, Aging and Retirement, 2, 230-261.

Fisher, G. G., Ryan, L. H., Sonnega, A., \& Naudé, M. N. (2016). Job lock, work, and psychological well-being in the United States. Work, Aging and Retirement, 2, 345-358.

Fletcher, J. M., Sindelar, J. L., \& Yamaguchi, S. (2011). Cumulative effects of job characteristics on health. Health Economics, 20, 553-570.

Geurts, S. A., \& Demerouti, E. (2003). Work/non-work interface: A review of theories and findings. The Handbook of Work and Health Psychology, 2, 279-312.

Greenhaus, J. H., \& Powell, G. N. (2006). When work and family are allies: A theory of work-family enrichment. Academy of management review, 31, 72-92.

Henkens, K. (1999). Retirement intentions and spousal support: A multi-actor approach. Journal of Gerontology: Social Sciences, 54B, S63-S74.

Hochschild, A., \& Machung, A. (2012). The second shift: Working families and the revolution at home. New York: Penguin Putnam.

Kiefer, T. (2002). Understanding the emotional experience of organizational change: Evidence from a merger. Advances in Developing Human Resources, 4, 39-61.

Kiefer, T. (2005). Feeling bad: Antecedents and consequences of negative emotions in ongoing change. Journal of Organizational Behavior, 26, 875-897.

Koolhaas, W., van der Klink, J. J., de Boer, M. R., Groothoff, J. W., \& Brouwer, S. (2014). Chronic health conditions and work ability in 
the ageing workforce: the impact of work conditions, psychosocial factors and perceived health. International Archives of Occupational and Environmental Health, 87, 433-443.

Koppes, L., Vroome, E. D., Mol, M., Janssen, B., \& Bossche, S. (2009). De Nationale enquête arbeidsomstandigheden 2008: methodologie en globale resultaten. Leiden, The Netherlands: TNO.

Kullmann, M., \& Rocca, M. (2016). Part-time work with part-time retirement: Towards an alliance between labour law and pensions for the healthy ageing of the workforce. Maastricht, the Netherlands: University of Maastricht.

Lazarus, R. S. (1991). Emotion and adaptation. Oxford, UK: Oxford University Press.

Little, T. D., Jorgensen, T. D., Lang, K. M., \& Moore, E. W. G. (2014). On the Joys of Missing Data. Journal of Pediatric Psychology, 39, 151-162.

Löckenhoff, C. E., Terracciano, A., \& Costa Jr, P. T. (2009). FiveFactor Model Personality Traits and the Retirement Transition: Longitudinal and Cross-Sectional Associations. Psychology and Aging, 24, 722-728.

Matthews, R. A., \& Fisher, G. G. (2013). Family, work, and the retirement process: A review and new directions. In M. Wang (Ed.), The Oxford Handbook of Retirement (pp. 354-370). New York, NY: Oxford University Press.

Monat, A., \& Lazarus, R. S. (1991). Stress and coping: An anthology. New York, NY: Columbia University Press.

Mortelmans, D., \& Vannieuwenhuyze, J. T. A. (2013). The agedependent influence of self-reported health and job characteristics on retirement. International Journal of Public Health, 58, 13-22.
OECD. (2015). Pensions at a Glance 2015. OECD and G20 indicators. Paris, France: Organisation of Economic Co-operation and Development.

Peeters, M. C., Montgomery, A. J., Bakker, A. B., \& Schaufeli, W. B. (2005). Balancing work and home: How job and home demands are related to burnout. International Journal of Stress Management, $12,43$.

Van den Berg, T. I., Elders, L. A., \& Burdorf, A. (2010). Influence of health and work on early retirement. Journal of Occupational and Environmental Medicine, 52, 576-583.

Van Solinge, H., \& Henkens, K. (2005). Couples' adjustment to retirement: A multi-actor panel study. Journals of Gerontology Series B-Psychological Sciences and Social Sciences, 60, S11-S20.

Van Solinge, H., \& Henkens, K. (2010). Living longer, working longer? The impact of subjective life expectancy on retirement intentions and behaviour. European Journal of Public Health, 20, 47-51.

Van Solinge, H., \& Henkens, K. (2014). Work-related factors as predictors in the retirement decision-making process of older workers in the Netherlands. Ageing and Society, 34, 1551-1574.

Wang, M., Henkens, K., \& van Solinge, H. (2011). Retirement adjustment. A review of theoretical and empirical advancements. American Psychologist, 66, 204-213.

Wang, M., \& Shultz, K. S. (2010). Employee retirement: A review and recommendations for future investigation. Journal of Management, 36, 172-206.

Yu, I. T., \& Tse, S. L. (2012). Sources of bias in cross-sectional studies; summary on sources of bias for different study designs. Hong Kong Medical Journal, 18, 226-227. 